Indonesian Journal of Biotechnology, December, 2011

Vol. 16, No. 2, pp.88-92

\title{
Determination of Haemaglutinin and Gene Encoding Fibronectin Binding Proteins Staphylococcus aureus Isolated from Dairy Milk Cows
}

\author{
Feny Prabawati Pratomo ${ }^{1}$, Siti Isrina Oktavia Salasia ${ }^{2 *}$, and Syarifudin Tato ${ }^{3}$
}

\begin{abstract}
${ }^{1}$ Research Center for Biotechnology, Universitas Gadjah Mada, Yogyakarta, Indonesia
${ }^{2}$ Department of Clinical Pathology, Faculty of Veterinary Medicine, Universitas Gadjah Mada, Yogyakarta, Indonesia

${ }^{3}$ Departement of Pharmacology, Faculty of Veterinary Medicine, Universitas Gadjah Mada, Yogyakarta, Indonesia
\end{abstract}

\begin{abstract}
Staphylococcus aureus is a major pathogen causing clinical and subclinical mastitis in dairy milk cows. The mastitis has immense economical impacts, where it reduces of the quantity and quality of milk production. The aims of the research were to analyse haemaglutinin and gene encoding fibronectin binding proteins. Nineteen Staphylococcus aureus isolates used in the present study were isolated from dairy milk cows from Yogyakarta, Solo, Boyolali and Sumedang. The haemagluitinin of S. aureus were determined based on haemaglutination reaction to erythrocytes of rabbit. Detection of gene encoding fibronectin binding proteins could be performed with specific primers using polymerase chain reaction (PCR). The results of studies showed that most of $S$. aureus $(78,95 \%)$ expressed haemaglutinin based on their ability to aglutinate rabbit erythrocytes. Analysis of gene encoding fibronectin binding proteins of S. aureus revealed gene fnbA with size of approximately $1300 \mathrm{bp}$ for $57,89 \%$ isolates, gene fnbB with size of approximately $900 \mathrm{bp}$ for $31,58 \%$ isolates and both of gene $f n b \mathrm{~A}$ and $f n b \mathrm{~B}$ could be detected for $31,58 \%$ isolates. The characters of $S$. aureus based on haemaglutinin, gene $f n b \mathrm{~A}$ and $f n b \mathrm{~B}$ of the present study could be used as an information to control of $S$. aureus infection in dairy herds.
\end{abstract}

Keywords : Staphylococcus aureus, haemaglutinin, gene encoding fibronectin binding protein, milk cow

\section{Introduction}

Staphylococcus aureus is world wide recognized as a major pathogen causing subclinical intramammary infections in dairy cows. Intramammary infections can cause high economic loss especially because of decreasing up to $10-25 \%$ of the total milk cows production (Han et al., 2000). Staphylococcus aureus from the environment available to contaminate fresh milk during milking of cows or during milk processing (Morandi et al. , 2007).

"Corresponding author:

Siti Isrina Oktavia Salasia

Department of Clinical Pathology, Faculty of Veterinary Medicine, Universitas Gadjah Mada, Yogyakarta, Indonesia,

Email:_isrinasalasia@ugm.ac.id
The ability of $S$. aureus to infect the hosts are supported by their ability to produce toxins, enzymes and surface proteins of the bacteria. Adhesin or haemaglutinin is a protein that play role in adhesion of $S$. aureus to host cells. The existence of $S$. aureus adhesin could be determined by haemaglutination reaction and amplification of genes encoding fibronectin binding protein. In dairy cattle, the adhesion process of $S$. aureus to the host cells correlates with the pathogenesis of mastitis. Fibronectin binding proteins (FnBP) are important factors in course of adhesion of $S$. aureus to milk cow glands. This proteins are encoded by fnbA and $f n b B$ genes (Nasev et al, 2004; Pohlman-Dietze et al, 2000)

The control of $S$. aureus infection is recently developed based on character 
of phatogenecity which is vary between countries. In Indonesia, the mapping of the characters and the phylogenetic nature of the $S$. aureus population have not been well done, thus the $S$. aureus infection can not be controled completely. The aims of this study were to characterize $S$. aureus phenotypic and genotypically through the detection of haemaglutinin and the existence of genes encoding fibronectin binding proteins among S. aureus isolated from dairy milk cows from various origins.

\section{Materials and Methods \\ Bacterial Isolates}

Nineteen Staphylococcus aureus isolates used in the present study were isolated from dairy milk cows from Yogyakarta, Solo, Boyolali and Sumedang. The identification of $S$. aureus were performed based on Gram staining, fermentation of mannitol salt agar (MSA), catalase and coagulase assays. Molecular identification of the S. aureus 23S rRNA genes was conducted by PCR using oligonucleotide species specific primers (Table 1).

\section{Haemaglutinin and Fibronectin Binding Protein Assays}

The haemaglutinin of $S$. aureus was determined based on haemaglutinating reaction to erythrocytes of rabbit. The genes encoding fibronectin binding proteins were determined by using PCR with specific primers (Table 1).

\section{Preparation of DNA}

The bacterial DNA was prepared with the QIAamp tissue kit as described by the manufacturer (Qiagen). After cultivation of the isolates for $24 \mathrm{~h}$ at $37^{\circ} \mathrm{C}$ on blood agar plates, 5-10 colonies of the bacteria were suspended in TE buffer $(10 \mathrm{mM}$ Tris- $\mathrm{HCl}, 1$ mMEDTA ( $\mathrm{pH} 8)$ ) containing $5 \mu$ lysostaphin $(1.8 \mathrm{U} / \mu \mathrm{l}$; Sigma). After $1 \mathrm{~h}$ incubation at $37^{\circ} \mathrm{C}, 25 \mu \mathrm{l}$ of proteinase $\mathrm{K}(14,8 \mathrm{mg} / \mathrm{mL}$; Sigma) and $200 \mu \mathrm{l}$ of buffer AL (containing reagents AL1 and AL2) were added. The suspension was incubated for $30 \mathrm{~min}$ at $56^{\circ} \mathrm{C}$ and for $10 \mathrm{~min}$ at $95^{\circ} \mathrm{C}$, and after a spin for a few secs an amount of $420 \mu \mathrm{l}$ ethanol was added to each sample and placed in a spin column. After centrifugation for $1 \mathrm{~min}$, the QIAamp spin columns were placed in a clean collection tube and the samples were washed twice with $500 \mu \mathrm{l}$ of buffer AW (Qiagen). After a sec wash and a centrifugation for 3 min, the QIAamp spin columns were placed in a clean $2 \mathrm{~mL}$ microfuge tube and the DNA was twice eluted with $200 \mu \mathrm{l}$ and $100 \mu \mathrm{l}$ of buffer $\mathrm{AE}$, respectively. The DNA could be stored at $-20^{\circ} \mathrm{C}$. Amplification reactions with PCR were performed by program and specific primer according to the references for $23 S$ rRNA and $f n b \mathrm{~A}$ and $f n b \mathrm{~B}$ genes. PCR products were then separated by gel electrophoresis in a $1.5 \% \mathrm{w} / \mathrm{v}$ agarose (Seakem) gel run in $0.5 \times \mathrm{TBE}$ buffer. The $1 \mathrm{~kb}$ Plus DNA ladder (Invitrogen) was used as a size marker. Resulting bands were visualized with cyber safe by UV transillumination.

Tabel 1. Primer and PCR programs for amplification of 23SrRNA gene and genes encoding fibronectin binding proteins

\begin{tabular}{|c|c|c|c|c|}
\hline Gene & $\begin{array}{l}5^{\prime} \text { primer sequence } \\
\left(5^{\prime} \rightarrow 3^{\prime}\right)\end{array}$ & $\begin{array}{l}3^{\prime} \text { primer sequence } \\
\left(3^{\prime} \rightarrow 5^{\prime}\right)\end{array}$ & Program* & Reference \\
\hline 23S rRNA & $\begin{array}{l}\text { AGC GAG TTA CAA } \\
\text { AGG ACG AC }\end{array}$ & $\begin{array}{l}\text { AGC TCA GCC TTA } \\
\text { ACG AGT AC }\end{array}$ & 1 & Straub et al., 1999 \\
\hline$f n b \mathrm{~A}$ & $\begin{array}{l}\text { GCG GAG ATC AAA } \\
\text { GAC AA }\end{array}$ & $\begin{array}{l}\text { CCA TCT ATA GCT } \\
\text { GTG TGG }\end{array}$ & 2 & Signas et al., 1989 \\
\hline$f n b B$ & $\begin{array}{l}\text { GGA GAA GGA ATT } \\
\text { AAG GCG }\end{array}$ & $\begin{array}{l}\text { GCC GTC GCC TTG } \\
\text { AGC GT }\end{array}$ & 2 & Jonsson et al., 1991 \\
\hline
\end{tabular}

${ }^{*} 1: 37$ cycles $\left(94^{\circ} \mathrm{C} .40 \mathrm{~s}, 64^{\circ} \mathrm{C} .60 \mathrm{~s}, 72^{\circ} \mathrm{C} .75 \mathrm{~s}\right) ; 2: 30$ cycles $\left(94^{\circ} \mathrm{C} .30 \mathrm{~s}, 50^{\circ} \mathrm{C} .30 \mathrm{~s}, 72^{\circ} \mathrm{C} .60 \mathrm{~s}\right)$ 


\section{Results and Discussions}

Based on biochemical and molecular identification showed that all 19 isolates used in this study were $S$. aureus. All S. aureus were Gram positive, fermented mannitol salt agar (MSA), catalase and coagulase positive. The genotypic identification showed that 235 rRNA gene could be amplified by PCR from all S. aureus isolates. This target genes allowed a rapid identification of this species with high sensitivity and specifity (Salasia et al., 2004b).

Haemaglutinin of $S$. aureus was determined based on haemaglutinating reaction. Haemaglutination by $S$. aureus relate to mastitis pathogenesis in cows. It was reported that more than $75 \%$ of $S$. aureus strains causing mastitis mediated by haemaglutination. Haemaglutination also related to $S$. aureus adherence in human epithelial cells (Rupp et al., 1995).

The results of haemaglutinating reaction indicated that most of $S$. aureus could aglutinate erythrocytes of rabbit (15 isolates $/ 78,95 \%$ ). Haemaglutinin play an important role on adhesion, at the preliminary colonization of the bacteria on the surface of intramammary ephitelial cells. Staphylococcus aureus with haemaglutinin positive were more adhesive to intramammary epithielial cells than haemaglutinin negative $S$. aureus. The role of haemaglutinin on adhesion was predicted as an important factor for $S$. aureus virulence (Wahyuni et al., 2005).

Some $S$. aureus strains used in the study showed no reaction with erythrocytes of rabbit. Wahyuni (2002) reported that $S$. aureus isolates which have no haemaglutination activity, might be have haemaglutinin but its existence were covered by capsule on the surface of bacteria. Abrar (2001) reported that polysacharide capsules of S. aureus have an important role of subclinical mastitis of cows. This capsules could cover the expression of haemaglutinin. The results of haemaglutinating reaction $S$. aureus isolated from dairy milk cows from various origins are presented in Table 2.

The microbial adherence to cells and extracellular matrix are considered as an essential step in the process of colonization and infection of S. aureus (Nashev et al., 2004). Fibronectin binding protein play a role towards adhesion of $S$. aureus to the epithelial cells and milk gland cells of cows (Pohlmann-Dietze et al., 2000; Salasia et al., 2004a). Binding towards fibronectin are mediated by two protein FnBPA and FnBPB which are encoded by genes fnbA and $f n b B$ respectively (Nashev et al., 2004). Ligand binding region of fibronectin binding proteins (FnBPA and FnBPB) are located in C-terminal D repeats (Hartford, 1999).

Amplification of $f n b \mathrm{~A}$ and $f n b \mathrm{~B}$ genes in the recent study showed the amplicons as informed at the previous study by Nashev et al. (2004). The fnbA gene has an amplicon with size of approximately $1300 \mathrm{bp}$ (Figure 1) and $900 \mathrm{bp}$ for fnbB gene (Figure 2).

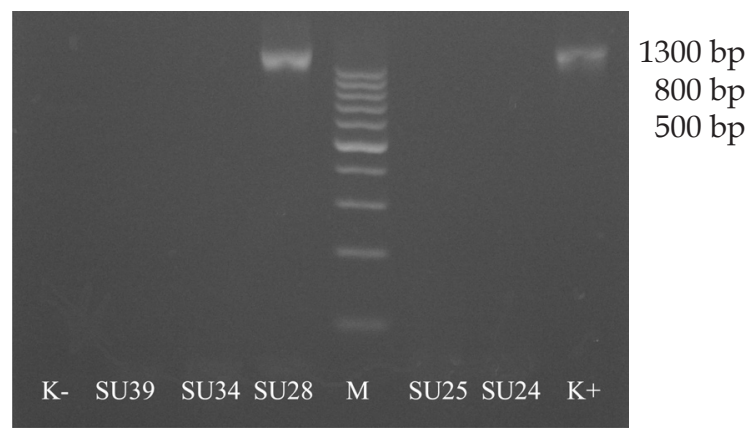

Figure 1. Amplification of fnbA gene of $S$. aureus with size of approximately 1300 bp. M (marker DNA, Fermentas), $\mathrm{K}$ - (negative control), SU39, SU34 (isolates from dairy milk cows from Solo), SU28, SU25, SU24 (isolates from dairy milk cows from Yogyakarta), K+ (positive control).

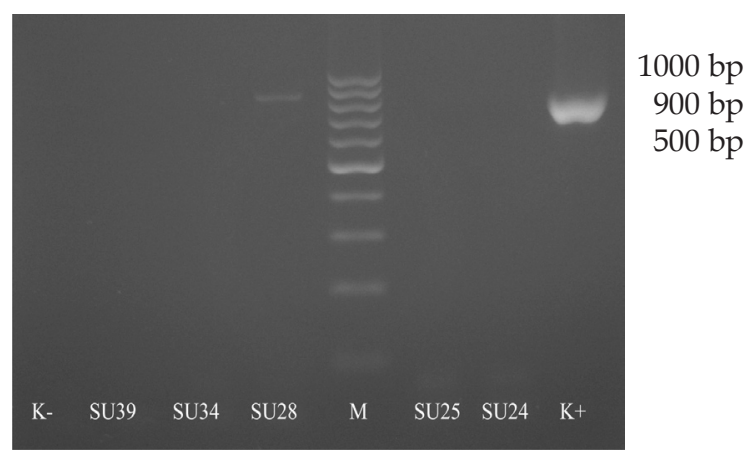

Figure 2. Amplification of $f n b \mathrm{~B}$ gene of $S$. aureus with size of approximately 900 bp. M (marker DNA, Fermentas), $\mathrm{K}$ - (negative control), SU39, SU34 (isolates from dairy milk cows from Solo), SU28, SU25, SU24 (isolates from dairy milk cows from Yogyakarta), $\mathrm{K}+$ (positive control). 
Staphylococcus aureus isolated from dairy milk cows from various origins could be detected fnbA gene for 11 isolates $(57,89 \%)$, included six isolates from Yogyakarta (SU2, SU5, SU28, Y5 Y7), one isolate from Solo (SU47), 2 isolates from Boyolali (BY5, BY7) and three isolates from Sumedang (I4, Jaed2, P1). Staphylococcus aurues strains used in the study revealed $f n b \mathrm{~B}$ gene for 6 isolates $(31,58 \%)$, included 4 isolates from Yogyakarta (SU2, SU28, Y5, Y7) and 2 isolates from Boyolali (BY5, BY7). Combination of fnbA and fnbB genes of Staphylococcus aureus could be detected for $31,58 \%$ isolates (Table 2).

The characterisation of $S$. aureus isolated from dairy milk cows from various origins based on phenotypic and genotypic are presented in Table 2. Group I showed that $S$. aureus strains SU2 and SU28 had the same phenotypic and genotypic characters. These strains were haemaglutination positive and revealed both genes encoding fibronectin binding proteins ( $f n b \mathrm{~A}$ and $f n b \mathrm{~B})$. S. aureus strains SU47 and SU5 showed also the same phenotypic and genotypic characters, and these strains were positive haemaglutination and positive of the gene frb A, but negative gene fribB. Staphylococcus aureus of group II showed the same character of phenotypic- and genotypically, positive on haemaglutination reaction, but negative of both gene encoding fibronectin binding proteins ( $n b \mathrm{~A}$ and $f n b \mathrm{~B})$. The group III of $S$. aureus showed various characters of phenotypicand genotypically. However, group IVof $S$. aureus showed that all strains were positive haemaglutination reaction and had both genes encoding fibronectin binding proteins (fnbA and fnbB). S. aureus strains used in the recent study which have the same character phenotypic-and genotypically character could be grouped into the same cluster.

The results of haemaglutination reaction and the existence of genes encoding fibronectin binding proteins ( $f n b \mathrm{~A}$ and $f n b \mathrm{~B}$ ) of $S$. aureus isolates from milk cows from various origins in Indonesia might use as a basic epidemiology study and control of $S$. aureus infections in herds.
Table 2. Haemaglutination reaction and genes encoding fibronectin binding proteins of Staphylococcus aureus isolated from dairy milk cows from various origins

\begin{tabular}{cccccc}
\hline No & $\begin{array}{c}\text { Code } \\
\text { of } \\
\text { Isolate }\end{array}$ & $\begin{array}{c}\text { Origin of } \\
\text { Isolate }\end{array}$ & $\begin{array}{c}\text { Haema- } \\
\text { glutination } \\
\text { reaction }\end{array}$ & $\begin{array}{c}\text { fnbA } \\
\text { gene }\end{array}$ & fnbB \\
gene
\end{tabular}

\section{Acknowledgements}

This research was a part of the research results funded by Ministry of Education Republic of Indonesia through Hibah Kompetensi Program 2008-2010. The authors would acknowledge drh. Sugiyono, M.Sc. for help in the research in Clinical Pathology Laboratory and drh. Khusnan, MP., Academy of Farming Brahmaputra for help in collecting rabbit and sheep blood.

\section{References}

Abrar, M., 2001. Isolasi, Karakterisasi dan Aktivasi Biologi Hemaglutinin S. aureus dalam Proses Adesi pada Permukaan Sel Epitel Ambing Sapi Perah. Disertasi. Program Pascasarjana Institut Pertanian Bogor.

Han, H. -R, Park, S. -I., Kang, S. -W., Jong, W. -S. and Youn, C. -J. 2000. Capsular Polisaccharide Typing of Domestic Mastitis-causing Staphylococcus aureus Strains and Its Potential Exploration of 
Bovine Mastitis Vaccine Development. I. Capsular Polysaccharide Typing, Isolation and Purification of the Strain. J. Vet. Sci. 1, 53-63.

Hartford, O., McDevitt, D., and Foster, T. J. 1999. Matrix-binding Proteins of Staphylococcus aureus: Functional Analysis of Mutant and Hybrid Molecules. Microbiol. 145, 2497-2505.

Jonsson, K., Signas, C., Muller, H.P., and Lindberg, M. 1991. Two different genes encode fibronectin binding protein in Staphylococcus aureus-The complete nucleotide sequence and characterization of the second gene. Eur.J.Biochem., 202, 1041-1048

Morandi, S., Brasca, M., Lodi, R., Cremonesi, P. and Castiglioni, B. 2007. Detection of Classical Enterotoxins and Identification of Enterotoxin Genes in Staphylococcus aureus from Milk and Dairy Products. Vet. Microbiol. 124, 66-72.

Nashev, D., Toshkova, K., Salasia, S. I. O., Hassan, A. A., Lammer, C. and Zschock, M. 2004. Distribution of Virulence Genes of Staphylococcus aureus Isolated from Stable Nasal Carriers. FEMS Microbiol. Lett. 233, 45-52.

Pohlmann-Dietze, P., Ulrich, M., Kiser, K. B., Doring, G., Lee, J. C., Fournier, J. M., Botzenhart, K. and Wolz, C. 2000. Adherence of Staphylococcus aureus to Endothelial Cells: Influence of Capsular Polysaccharide, Global Regulator agr, and Bacterial Growth Phase. Infect. Immun. 68, 4865-4871.

Rupp, M. E., Han, J. and Gatermann, S. 1995. Hemagglutination by Staphylococcus aureus Strains Responsible for Human Bacteremia or Bovine Mastitis. Med. Microbiol. Immunol. 184, 33-36.

Salasia, S. I. O., Kusnan, Z., Lämmler, C. and Zschöck, M. 2004a. Comparative Studies on Pheno- and Genotypic Properties of Staphylococcus aureus Isolated from Bovine Subclinical Mastitis in Central Java in Indonesia and Hesse in Germany. J. Vet. 5 (2), 103-109.
Salasia, S. I. O., Khusnan and Artanto, S. 2004b. Distribution of cap5 and cap 8 Genes of Staphylococcus aureus Isolated from Subclinical Mastitis Cow in Central Java, Indonesia. I.J. Biotech. 701-705.

Signäs, C., Raucci, G., Jönsson, K., Lindgren, P.E., Anantharamaiah, G.M., Höök, M., and Lindberg, M. 1989. Nucleotide sequence of the gene for a fibronectinbinding protein from Staphylococcus aureus: use of this peptide sequence in the synthesis of biologically active peptides. PNAS. 1989 86(2), 699-703

Straub, J.A., Hertel, C., and Hammes, W.P. 1999. A 23s rDNA-targeted polymerase chain reaction-based system for detection of Staphylococcus aureus in meat starter cultures and dairy products. J.Food Prot., 62, 1150-1156

Wahyuni, A. E. T. H. 2002. Karakterisasi Fenotipe dan Genotip Streptococcus agalactiae Isolat Asal Indonesia Penyebab Mastitis Subklinis pada Sapi Perah. Program Pascasarjana. Institut Pertanian Bogor. Bogor.

Wahyuni, A. E. T. H. W., Wibawan, I. W. T. dan Wibowo, M. H. 2005. Karakterisasi Hemaglutinin Streptococcus agalactiae dan Staphylococcus aureus Penyebab Mastitis Subklinis pada Sapi Perah. J. Sain Vet. 23 (2), 79-86. 